Marta Guillermo-Sajdak

Uniwersytet Jagielloński, Kraków

marta.sajdak@wp.pl

\title{
MODELE STAWANIA SIĘ I BYCIA DWUJĘZYCZNYM PRZEDSTAWICIELI POLONII ARGENTYŃSKIEJ
}

Słowa klucze: dwujęzyczność, język polski, język hiszpański, Polonia argentyńska Keywords: bilingualism, Polish, Spanish, Polish diaspora in Argentina

\section{Masowa emigracja polska do Argentyny: 1897-1950}

Drugim po Brazylii krajem Ameryki Południowej, w którym osiedliła się największa liczba polskich emigrantów, jest Argentyna. Dzięki napływowi zagranicznego kapitału, nowej technologii oraz przede wszystkim za pośrednictwem imigrantów z Europy kraj ten stał się w pierwszej połowie XX w. jednym z najbogatszych państw świata. W latach 1857-1949 przybyło tu łącznie około siedmiu milionów Europejczyków (Mazurek 2006). Do Argentyny emigrowano licznie z dwóch powodów: z racji łatwości uzyskania darmowych biletów na statek, co wskazywało na determinację tego kraju w pozyskiwaniu europejskich emigrantów, oraz dostępności ziemi, szczególnie w północnej prowincji Misiones.

Pierwszymi Polakami, którzy dotarli do Argentyny, byli żołnierze kampanii napoleońskich. Przez cały XIX w. przybywali tu ludzie wykształceni (kartografowie, nauczyciele, księża, lekarze, etnografowie, geolodzy), którzy brali udział w kształtowaniu się kraju.

Zorganizowana imigracja polska rozpoczęła się w $1897 \mathrm{r}$. i celem jej było zaludnienie prowincji Misiones. W tym roku 14 polskich rodzin, pochodzących z Galicji, przybyło 
do portu w Buenos Aires, a następnie zostało odesłanych do Apóstoles w prowincji Misiones. Zasiedlili tam byłą misję jezuicką, opuszczoną od 1768 r. Była to emigracja chłopska, która dostała ziemie uprawne od rządu argentyńskiego. Do dziś mieszkańców tego regionu nazywa się apóstolopolacos. W późniejszym czasie Polacy zasiedlili także inne miejsca prowincji: San José, Azara, Cerro Corá, Bonpland, Yerbal Viejo (dziś Oberá), Gobernador Roca i nieco później Colonia Lanusse, Colonia Wanda czy Colonia Polana.

Na początku XX w. w prowincji Chubut w Patagonii, w miejscu zwanym Comodoro Rivadavia, osiedliła się grupa polskich nafciarzy wraz z rodzinami. Byli to przede wszystkim inżynierowie, zatrudnieni przez firmę Yacimientos Petrolíferos Fiscales (YPF), zajmującą się wydobyciem ropy naftowej.

Również na początku XX w. grupa Polaków zainstalowała się w Berisso, mieście w prowincji Buenos Aires, znajdując zatrudnienie w przemyśle mięsnym.

W okresie międzywojennym mamy do czynienia z kolejną falą polskiej emigracji chłopsko-robotniczej, której przedstawiciele rozproszyli się po całej Argentynie, zasiedlając Buenos Aires, Mendozę, nowe kolonie w Misiones, Córdobę, Neuquén, Tucumán oraz Rosario.

Między 1946 a 1950 przybyli emigranci powojenni, w większości byli żołnierze oraz inteligencja wraz z rodzinami (w sumie 13 ooo osób) (Uzarowicz 1988), zamykając tym samym ostatnią polską falę imigracyjną do Argentyny (zob. Pyzik 1966; Wróbel 1999; Bryszewska, Gmitruk, Mazurek 2004; Stemplowski 2011).

Dzisiaj mówi się o czterech generacjach Polonii argentyńskiej, liczącej około 300 ooo osób ${ }^{1}$, która w większości jest hiszpańskojęzyczna. Dla reprezentantów pierwszej oraz drugiej generacji język polski pełni rolę języka ojczystego lub drugiego. Natomiast dla przedstawicieli trzeciej i czwartej generacji język polski jest zwykle językiem obcym, którego osoby te uczą się na różnego rodzaju kursach organizowanych przez Związki Polaków w Argentynie lub który po prostu znają „ze słyszenia”.

\section{Założenia badań}

Niniejszy artykuł stanowi podsumowanie badań terenowych poświęconych dwujęzyczności Polonii argentyńskiej, prowadzonych przeze mnie w latach 2009-2011 w prowincjach Buenos Aires, Santa Fe, Córdoba oraz Misiones. W tym czasie zrealizowałam

1 Brak danych urzędowych sprawia, iż możliwa jest tylko szacunkowa ocena liczebności Polonii argentyńskiej. Ustalenie dokładnej liczby nie jest proste. Problem ten uwidacznia się w znaczących wahaniach statystycznych, pojawiających się w opracowaniach na ten temat. Na przykład EPEiP na podstawie danych z 1995 r. podaje liczbę 170 ooo osób, natomiast w 2004 r. Ambasada Polski w Buenos Aires doniosła, iż współczesna społeczność polonijna w Argentynie wyniosła 400000 osób. Informacja ta została zatwierdzona w tym samym roku przez Senat RP.

Powyższe dane uzyskano podczas oficjalnej rozmowy z konsul Moniką Konieczny w Ambasadzie RP w Buenos Aires (grudzień 2011 r.). Por. Argentyna w: EPEiP. 
102 badania ankietowe oraz nagrałam i przeanalizowałam pod względem językowym 62 wywiady z reprezentantami czterech generacji Polonii argentyńskiej².

Kryterium doboru grupy badawczej było dosyć szerokie:

1. Osoby miały należeć do jednej z czterech generacji Polonii argentyńskiej.

2. Badani mieli używać naprzemiennie (przez pewien okres życia lub stale) w zależności od sytuacji i środowiska - języka polskiego oraz hiszpańskiego (por. GDL\&SL), bez względu na kompetencję językową osiągniętą w obu tych językach; pod uwagę zostały wzięte także osoby polskiego pochodzenia obecnie uczące się języka polskiego jako obcego.

Osoby, które zgodziły się wziąć udział w badaniu, to między innymi moi obecni lub byli uczniowie, działacze polonijni, czynni uczestnicy życia polonijnego w Argentynie oraz znajomi i przyjaciele. Oprócz nagranych wywiadów przeprowadzonych w języku polskim i hiszpańskim badaniom towarzyszyła obserwacja uczestnicząca oraz analiza zebranych dokumentów (prac pisemnych uczniów, listów, kartek pocztowych czy korespondencji mailowej utrzymywanej z 46 osobami spośród 62 badanych). 21 rozmówców pochodziło z prowincji Buenos Aires, 17 z Misiones, 11 z Córdoby, 8 z Santa Fé. Dwie osoby, z którymi wywiad został nagrany w kolonii Wanda (w Misiones), mieszkają na co dzień w sąsiedniej prowincji Chaco. Z trzema rozmówcami mieszkającymi w Patagonii (dwie osoby z prowincji Chubut oraz jedna z Río Negro) wywiady przeprowadziłam drogą telefoniczną.

Mężczyźni byli rozmówcami w 28 wywiadach, a kobiety - w 34. Wiek badanych wahał się między 19 a 95 rokiem życia, z czego największą grupę stanowiły osoby $\mathrm{w}$ przedziale od 45 do 65 lat. Respondenci byli przedstawicielami czterech generacji Polonii argentyńskiej: pierwszą z nich reprezentowało 12 osób, drugą -26 , trzecią -17 , a czwartą -7 .

Wszystkie wywiady były ukierunkowane i opierały się na tym samym schemacie: od danych personalnych, poprzez historię emigracji, biografię językową i akulturacyjną, po uczestnictwo w kulturze symbolicznej Polski oraz Argentyny. Przydatność tej metody badawczej, polegającej na nagrywaniu wywiadów pogłębionych, jest duża, gdyż mnogość odpowiedzi na wybrane tematy z jednej strony weryfikuje i uściśla uzyskane informacje o charakterze ogólnym (historycznym, socjologicznym), z drugiej - ułatwia obserwację zróżnicowania językowego informatorów.

Większość wywiadów została przeprowadzona wyłącznie w języku polskim (43 wywiady), ale bardzo często uczestnicy $w$ trakcie wypowiedzi przechodzili na język hiszpański, szczególnie jeśli rozmowa dotyczyła trudniejszych zagadnień i przeżyć

2 Wszystkie materiały zostały nagrane na dyktafon i zarejestrowane na płytach CD w postaci 28-godzinnego dokumentu. Długość pojedynczych wywiadów wahała się między 25 a 40 minut. Wśród nagrań znalazły się także trzy rozmowy telefoniczne, przeprowadzone z reprezentantami Polonii patagońskiej, z którymi nie miałam okazji porozmawiać osobiście. 
lub kiedy interlokutorzy chcieli uzupełnić informację przekazaną w języku polskim i upewnić się, że na pewno zostali dobrze zrozumiani. 16 respondentów udzieliło wywiadu w dwóch językach, a trzy osoby (znające słabo język polski) odpowiadały po hiszpańsku na zadawane po polsku pytania.

Na potrzeby artykułu spośród 62 wywiadów wybrałam kilku przedstawicieli Polonii argentyńskiej, którzy w najlepszy sposób obrazują proces stawania się i bycia dwujęzycznym oraz pozwalają wskazać rodzaje bilingwizmu polsko-hiszpańskiego spotykane dziś w Argentynie.

Imię jest ważnym elementem tożsamości człowieka, dlatego imiona respondentów (za ich zgodą) zostały przytoczone w oryginalnej formie, w której wystąpiły $\mathrm{w}$ nagraniach. Przedstawienie się polskim imieniem, często zdrobnionym, lub jego hiszpańskim odpowiednikiem jest ważnym sygnałem wyboru drogi akulturacyjnej reprezentantów kolejnych generacji polonijnych. Jeśli przedstawiciel pierwszego pokolenia w rozmowie przedstawia się „Andrés” zamiast „Andrzej” - może to być pierwszy sygnał informujący, że osoba ta przyjęła postawę integracyjną wobec nowego środowiska społeczno-kulturowego. Oczywiście tezę tę należy poprzeć szczegółowymi danymi z nagrywanego wywiadu. Przykładowo, 8o-letnia reprezentantka drugiego pokolenia Polonii argentyńskiej, przedstawiająca się jako „Marysia”, zapytana o świadomość wyboru polskiego zdrobnienia, odpowiedziała:

Tak zwracali się do mnie moi rodzice i ta właśnie „Marysia” oddaje najlepiej to, kim jestem - Polką w Argentynie. W sytuacjach oficjalnych muszę być „Marią”, z hiszpańskim akcentem nad „i”, ale moi argentyńscy znajomi, przyjaciele i cała rodzina nazywają mnie po prostu „Marysią”. To właśnie wyróżnia mnie spośród wszystkich kobiet noszących popularne w Argentynie imię „María” zdrabniane jako „Marita” lub „Maruja” (Buenos Aires, 12 XII 2011).

Ważnym punktem odniesienia dla moich badań było osiem modeli stawania się oraz bycia dwujęzycznym opisanych przez Władysława Miodunkę (2003). Monografia ta zasługuje na szczególną uwagę, gdyż jest to jedyna do tej pory praca poświęcona bilingwizmowi Polonii latynoamerykańskiej.

\section{Modele stawania się i bycia dwujęzycznym}

Pobyty w Argentynie i czas spędzony w gronie polonijnym pozwoliły mi na obserwację procesów stawania się i bycia dwujęzycznym indywidualnych reprezentantów czterech generacji polonijnych. W zdecydowanej większości przypadków ( $87 \%$ badanych $\left.^{3}\right)$ można mówić o bilingwizmie hiszpańsko-polskim, gdyż to właśnie znajomość języka hiszpańskiego (przez Polonię argentyńską nazywanego „kastylijskim”, „, argentyńskim”

354 osoby z 62 badanych deklarują znajomość języka hiszpańskiego w mowie oraz piśmie. 
lub „ríoplatense”) jest kompletna, zarówno jeśli chodzi o kod mówiony (rozumienie, mówienie), jak i o kod pisany (czytanie, pisanie). Polszczyzna aż w 47\% przypadków ogranicza się wyłącznie do znajomości kodu mówionego ${ }^{4}$. Wraz z upływem czasu i tendencjami asymilacyjnymi stały bilingwizm polsko-hiszpański utrzymuje się zaledwie w kilkunastu domach.

Większość przypadków stanowią reprezentanci bilingwizmu okazjonalnego, uwidaczniającego się wraz z aktywnościami polonijnymi: obchodami świąt narodowych i kościelnych, odwiedzinami gości z Polski, wyjazdami do Polski, wydarzeniami kulturalnymi związanymi z Polską, a także wizytami w konsulacie lub ambasadzie.

Na podstawie obserwacji uczestniczącej wyłoniłam cztery główne modele bilingwizmu charakteryzujące współczesną Polonię argentyńską:

1. Polski językiem ojczystym, hiszpański językiem drugim przyswojonym w okresie dorosłości.

2. Polski językiem pierwszym, hiszpański językiem drugim przyswojonym w okresie dzieciństwa.

3. Język polski „słodkim wspomnieniem dzieciństwa”, hiszpański językiem kariery zawodowej. Zapominanie języka etnicznego i powroty do niego.

4. Hiszpański językiem ojczystym, polski językiem obcym. W kierunku dwujęzyczności.

\section{Model 1. Polski językiem ojczystym, hiszpański językiem drugim przyswojonym w okresie dorosłości}

Jest to niewątpliwie model bilingwizmu polsko-hiszpańskiego dominujący wśród reprezentantów pierwszego pokolenia, znających język polski z domu oraz ze szkoły powszechnej. Wszyscy badani zakwalifikowani do tego modelu poznali podstawy polszczyzny literackiej przed opuszczeniem kraju rodzinnego, $w$ trakcie edukacji w polskiej szkole. W Argentynie osoby te nie miały okazji uczestniczenia w procesie sformalizowanej nauki języka hiszpańskiego, ale przyswajały go sobie stopniowo, w zależności od indywidualnych cech osobowościowych, talentu językowego i determinacji. Istotnymi czynnikami wewnętrznymi i zewnętrznymi pomocnymi w przyswajaniu języka hiszpańskiego okazały się: a) wiek emigranta; b) pochodzenie społeczne i charakter emigracji (tymczasowa, ekonomiczna, polityczna, indywidualna); c) wykształcenie; d) miejsce osiedlenia (kolonia, wieś, miasteczko, miasto); e) praca zawodowa na emigracji; f) pochodzenie osób z najbliższego otoczenia (rodzina oraz środowisko); g) stopień opanowania języka polskiego $\left(\mathrm{J}_{1}^{5}\right)$ : kodu mówionego oraz pisanego; h) stopień uczestnictwa w argentyńskiej kulturze.

429 osób z 62 badanych deklaruje znajomość wyłącznie kodu mówionego w języku polskim.

$5 \mathrm{~J} 1$ - język pierwszy/ojczysty; J2 - język drugi; JO - język obcy. 
Wiek emigranta ma duże znaczenie w przyswajaniu języka kraju przyjmującego. Większość badanych, reprezentujących pierwszy model bilingwizmu polsko-hiszpańskiego, to przedstawiciele tzw. późnego bilingwizmu ${ }^{6}$, przez który rozumie się nabywanie języka drugiego lub obcego $\mathrm{w}$ dorosłym wieku. $\mathrm{Z}$ faktem tym wiążą się pewne utrudnienia natury biologicznej (aparat mowy i słuch fonematyczny zostały już ukształtowane pod wpływem J1, czyli w tym przypadku języka polskiego), a także psychologiczno-społecznej. Dorośli muszą nauczyć się słyszeć i rozróżniać warstwę brzmieniową nowego języka. Nawet po wielu latach nabywania języka w jego naturalnym środowisku są rozpoznawalni jako obcokrajowcy. Osoby przyswajające J2 w dorosłym wieku obawiają się braku akceptacji nowego społeczeństwa, wstydzą się mówić w obcym, słabo opanowanym języku, nie zawsze są zmotywowane, a często boją się utraty tożsamości i czują niechęć do: „[...] bycia kimś innym w innym języku" (Wróblewska-Pawlak 2004: 73). Przyswojenie nowego języka przychodzi im $z$ trudem i często towarzyszy mu poczucie stresu.

W przypadku przyswajania J2 nie bez znaczenia są pochodzenie społeczne, charakter emigracji, a także wykształcenie emigrantów. Do Argentyny emigrowali niepiśmienni chłopi, dla których największą wartością były ich polska rodzina oraz uprawa własnego kawałka ziemi. Osoby te nie odczuwały potrzeby integracji ze społeczeństwem argentyńskim, a nawet obawiały się kontaktu „z obcymi”, tworząc polskie kolonie w subtropikalnej selwie. Do Argentyny emigrowali także (szczególnie w okresie międzywojennym) polscy robotnicy, którzy chcieli zarobić określoną sumę pieniędzy i wrócić do Polski. Emigracja tymczasowa najczęściej zamieniała się w emigrację stałą, gdyż zbliżająca się II wojna światowa i obawa przed nią zatrzymywały te osoby w nowym kraju. Ich znajomość języka hiszpańskiego ograniczała się do rozumienia i produkcji prostych zwrotów oraz leksyki związanej $\mathrm{z}$ wykonywaną pracą.

Emigranci polityczni, mający wyższe wykształcenie i wywodzący się z polskiej inteligencji, bardzo często mieli silną motywację do nauki J2, którą było zachowanie podobnego statusu społeczno-ekonomicznego. Znajomość innych języków pomagała im w poznaniu kolejnego i w wielu przypadkach proces przyswajania J2 zakończył się powodzeniem, tzn. opanowaniem języka hiszpańskiego w mowie i piśmie na poziomie zaawansowanym (z bardziej lub mniej wyczuwalnym polskim akcentem).

W przypadku emigracji indywidualnej, najczęściej dobrowolnej, motywacja do przyswojenia $\mathrm{J}_{2}$ była wysoka i równoważna $\mathrm{z}$ chęcią pozostania w wybranym kraju. Znajomość języka gwarantowała imigrantowi możliwość pełnej integracji z nową rzeczywistością społeczno-kulturową.

6 Rozróżnienie na early - late bilingualism ze względu na wiek przyswojenia języka drugiego wprowadzają Jim Cummins i Merrill Swain (Bilingualism in Education, London 1986, s. 7; za: Wróblewska-Pawlak 2004: 69). 
W przyswajaniu J2 nie bez znaczenia jest miejsce osiedlenia imigrantów. Mieszkańcy polskich kolonii w Misiones, czy też Polacy zamieszkujący argentyńskie wsie, nie mieli takich samych możliwości kontaktu z J2 na co dzień, jak rodacy osiedlający się w argentyńskich miastach. Oddalenie od szkół, urzędów, sklepów i punktów usługowych, niedostępność środków masowego przekazu, niewielka rotacja ludności to tylko niektóre czynniki zewnętrzne hamujące bezpośredni kontakt z J2.

Praca zawodowa jest kolejnym ważnym punktem w procesie przyswajania języka. W zależności od tego, czy imigrant pracował w środowisku przyjmującym, czy też polonijnym, jego motywacja do nauki J2 była różna.

Pochodzenie osób z najbliższego otoczenia imigranta może wpływać pozytywnie lub hamująco na chęć komunikacji w nowym języku. W przypadku par mieszanych oraz w momencie, w którym nawiązują się pierwsze znajomości i przyjaźnie z reprezentantami kraju przyjmującego, sukces w przyswajaniu J2 jest większy niż w przypadku osób związanych wyłącznie ze środowiskiem polonijnym.

Jak się okazuje, im lepsza jest znajomość J1 (w mowie i piśmie) i im bardziej rozwinięta świadomość językowa imigrantów, tym łatwiej przyswajają oni nowy, często kolejny język. Dotyczy to w głównej mierze wykształconej emigracji politycznej, a także przedstawicieli emigracji indywidualnej.

Uczestnictwo w kulturze symbolicznej kraju przyjmującego, możliwe dzięki dobrej znajomości J2, powoduje z jednej strony poszerzenie kompetencji językowych (poprzez poznawanie między innymi dzieł literackich, filozoficznych, religijnych, teatralnych czy filmowych), z drugiej strony jest najszybszą drogą do pełnej integracji $\mathrm{z}$ nową kulturą i jego rezultatem może być bilingwizm dwukulturowy ${ }^{7}$.

Spośród respondentów najszybciej przyswoiły język hiszpański te osoby, które znalazły pracę w środowisku argentyńskim, lub te, które założyły polsko-argentyńską rodzinę. W tych przypadkach często można mówić o integracji imigrantów i o ich dwujęzyczności dwukulturowej. Najwolniej natomiast uczyły się języka osoby (częściej kobiety niż mężczyźni) niepracujące zawodowo, lecz zajmujące się prowadzeniem domu; tutaj często spotykanym modelem bilingwizmu jest dwujęzyczność jednokulturowa ${ }^{8} \mathrm{w}$ konsekwencji prowadząca do separacji imigranta.

Większość reprezentantów pierwszego modelu dwujęzyczności to osoby w podeszłym wieku (między 85 a 95 rokiem życia). Brak nowej fali emigracyjnej sprawia, że ten typ bilingwizmu w Argentynie odejdzie wkrótce do historii.

7 Dwujęzyczność dwukulturowa - jednostka dwujęzyczna identyfikuje się z dwiema grupami kulturowymi posługującymi się jej pierwszym i drugim językiem, a ponadto przez każdą z tych grup rozpoznawana jest jako członek; ten typ dwujęzyczności odpowiada zjawisku i n t e g r a c j i imigrantów. Typologia dwujęzyczności według Josiane Hammers i Michel Blanc za: Wróblewska-Pawlak 2004: 32-34.

8 Dwujęzyczność jednokulturowa - jednostka dwujęzyczna posługuje się dwoma językami, ale identyfikuje się tylko z jedną z grup kulturowych; w tym przypadku mowa jest o separacji imigrantów (za: Wróblewska-Pawlak 2004: 158). 
Warto jednak przedstawić sylwetki Ireny i Leona:

Irena: przedstawicielka pierwszego pokolenia emigracyjnego, urodzona w $1926 \mathrm{r}$. w Toruniu. $Z$ zawodu bibliotekarka oraz nauczycielka języka polskiego. Jej ojciec był zawodowym oficerem - żołnierzem II Korpusu Polskiego i brał udział w walkach na froncie, między innymi w słynnej bitwie o Monte Cassino. W 1944 r. dom rodzinny w Warszawie został zbombardowany przez Niemców, a Irenie wraz z matką i siostrą udało się uciec z palącego się budynku. Z pomocą Czerwonego Krzyża kobiety przedostały się do Włoch, by tam spotkać się z ojcem. Po zakończeniu wojny rodzina trafiła do Anglii. W Londynie Irena poznała Polaka - byłego żołnierza i wkrótce wyszła za niego za mąż. Młodzi rozważali możliwość emigracji do Kanady, ale od imigrantów wymagano dużych zasobów finansowych, którymi rodzina nie dysponowała. Argentyna obiecywała pracę i udogodnienia mieszkaniowo-bytowe. Jedynym wymogiem formalnym było prześwietlenie płuc.

22-letnia respondentka przybyła do Buenos Aires w towarzystwie rodziców, siostry oraz męża, w 1948 r. Początki w nowym kraju wspomina bardzo źle. Z jednej strony obciążenie psychiczne w postaci wojennych wspomnień, $\mathrm{z}$ drugiej problemy materialne i nieznana rzeczywistość. Na początku cała pięcioosobowa rodzina mieszkała w jednym wynajętym pokoju. Irena dosyć szybko znalazła pracę w fabryce pończoch, potem dwa lata pracowała w porcie, następnie w laboratorium medycznym. Przyswojenie języka hiszpańskiego zajęło jej około pięciu lat, a w procesie tym pomogła badanej dobra znajomość języka francuskiego. Początkowo uczyła się „ze słuchu”, z czasem zaczęła czytać argentyńską prasę oraz książki. Twierdzi, że od samego początku trafiała na bardzo wyrozumiałych i wspaniałych ludzi, którzy jej pomagali - także językowo. W 1973 r. zmarł jej mąż. Wspomina go tak: „Nie poradził sobie z emigracją. Męczyły go demony wojny. Tu na miejscu nie potrafił się odnaleźć, tęsknił, nie był spełniony zawodowo. O psychologu nikt $\mathrm{z}$ nas nie pomyślał. Teraz, z perspektywy czasu wiem, że miał depresję".

Język polski był dla Ireny językiem rodzinnym, natomiast język hiszpański stał się językiem nowego środowiska, z którym pragnęła się zintegrować. Dopiero w momencie przejścia na emeryturę mogła sobie pozwolić na działalność polonijną. Przez osiem lat była dyrektorką Biblioteki Polskiej im. Ignacego Domeyki. Od 1991 r. naucza języka polskiego dorosłych oraz prowadzi kółko literacko-teatralne „Metafora”. Czynnie uczestniczy w życiu kulturalnym Buenos Aires.

Jak sama podkreśla, do polskości podchodzi bardzo racjonalnie. Spytana o reakcję na słowo „Polska”, stwierdza, że nie czuje jakiegoś specjalnego poruszenia. Odwiedzając pięciokrotnie ojczystą ziemię, nie czuła się jak w domu, twierdząc, że zarówno Polska, jak i ona sama bardzo się zmieniły i to już nie jest jej kraj: „Będąc pierwszy raz w Polsce, po 36 latach nieobecności, czułam się jak w obcym kraju, w którym wszyscy mówili po polsku”. Nazywa siebie: „Polką z Buenos Aires”. Uważa, że w Argentynie jest rozpoznawana jako obcokrajowiec ze względu na inny akcent, ale od zawsze wszelkie uwagi są pozytywne. Nigdy nie czuła się dyskryminowana ze względu na swoje pochodzenie. Nie miała dzieci, w związku z czym po śmierci męża język polski przestał być językiem domu. Teraz używa go wyłącznie w pracy, nauczając oraz biorąc czynny udział w życiu polonijnym. 
Z respondentką wywiad został przeprowadzony w całości w języku polskim, w płynnej odmianie literackiej. Czasami pojawiały się wtrącenia z języka hiszpańskiego, najczęściej na początku lub pod koniec wypowiedzi ( $y$ bueno / es asi / si / no). Wiele nazw własnych respondentka przytaczała w języku hiszpańskim (całe życie mieszkałam w bario Belgrano / jeździliśmy z mężem tam, gdzie zaczynają się los Andes I nigdy nie byłam po stronie oceanu Pacífico). Badana ocenia siebie jako osobę w pełni dwujęzyczną, gdyż zarówno kompetencja komunikacyjna, jak i językowa rozwinięte są w obu językach w mowie oraz piśmie.

Leon: najstarszy z respondentów, urodzony we Lwowie w 1917 r., przedstawiciel pierwszego pokolenia, przybył do Argentyny w 1948 r. Przed wojną ukończył studia medyczne we Lwowie i w momencie wybuchu wojny postanowił dołączyć do Polskich Sił Zbrojnych organizowanych we Francji. Człowiek, który obiecał mu przewiezienie do granicy polsko-niemieckiej, oddał go w ręce Rosjan i tym sposobem Leon trafił do obozu pracy na Syberii. Do dzisiaj pamięta mrozy sięgające minus 6o stopni. W 1941 r., kiedy Hitler zaatakował Moskwę, Leon został zwolniony z łagrów. Ważył wtedy 36 kilogramów! Wraz z Armią Andersa przemierzył Europę, Indie, Irak, służąc jako lekarz. W trakcie tej wędrówki poznał Marię, z którą wziął ślub i z którą zdecydował się wyemigrować do Argentyny. Ponieważ żona zmarła 12 lat temu, Leon ponownie ożenił się z Polką wdową po koledze z wojska.

Leon stosunkowo szybko przyswoił sobie język hiszpański, gdyż znał dobrze łacinę oraz francuski. W 1950 r. zaczął pracować jako lekarz w klinice w Buenos Aires. Żona zajmowała się domem, który od samego początku był „domem otwartym”. To tu spotykali się Polacy, którzy mieli podobne doświadczenia wojenne, by dyskutować o przyszłości kraju. Razem wspierali się w trudach emigracji. Bywał u nich sam Witold Gombrowicz, który poproszony, spontanicznie udzielał lekcji filozofii. Jak wspomina respondent: „Był to człowiek bardzo ekscentryczny, zawsze elegancki w kapeluszu i z zapaloną fajką - prawdziwy arystokrata. Dopiero jak światła gasły i widownia rozchodziła się do swoich domów, prosił moją żonę, by pożyczyła mu świeży ręcznik lub prześcieradło".

Badany czuje się Polakiem w Argentynie. Na początku emigracja była dla niego bardzo ciężka, ale z czasem przyzwyczaił się do nowych warunków życia. Tu znalazł swój drugi dom i przyjaciół. O swojej drugiej ojczyźnie mówi tak: „Argentyna to chyba jedyny kraj na świecie, który tak dobrze przyjął emigrantów bez względu na pochodzenie, wyznanie czy wiek - dał im takie same prawa, jakie mają Argentyńczycy. Ja mam dowód osobisty i mogę głosować w wyborach. Oczywiście «ziemia obiecana» przysparzała dużo problemów i trosk, ale wysiłek w większości przypadków się opłacił”. Do dziś Leon uczestniczy w spotkaniach Stowarzyszenia Kombatantów Wojennych, ale niestety z roku na rok ich grupa się zmniejsza. Zapytany o swoje pobyty w Polsce, mówi: „To rzadkie uczucie, którego doświadczyłem, bo będąc w Polsce, czułem się, jakbym nigdy jej nie opuszczał, a wysiadając z samolotu w Buenos Aires, miałem wrażenie, że nareszcie jestem $\mathrm{z}$ powrotem $\mathrm{w}$ domu".

Wywiad odbył się w całości w języku polskim, w pięknej odmianie literackiej, z przedniojęzykowo-zębowym [1]. 
Zarówno Irena, jak i Leon funkcjonują $\mathbf{w}$ dwóch językowych światach $\mathrm{z}$ własnego wyboru, wynikającego $\mathrm{z}$ chęci integracji $\mathrm{z}$ nowym środowiskiem poprzez pracę zawodową, kontakty międzyludzkie, uczestnictwo w kulturze kraju przyjmującego i co za tym idzie świadome przyswajanie zarówno kodu mówionego, jak i pisanego J2. Takie zachowania charakteryzują głównie grupę emigrantów politycznych, czyli wykształconych Polaków przybyłych do Argentyny po II wojnie światowej. Wśród badanych znalazło się wiele osób z podobną przeszłością: głównie byłych żołnierzy, ale także intelektualistów, inżynierów, artystów oraz ich rodziny, którzy najczęściej osiedlali się w prowincji Buenos Aires i chcieli jak najszybciej zintegrować się z nowym środowiskiem. Solidne przedwojenne wykształcenie, znajomość innych języków (łaciny, francuskiego, niemieckiego lub angielskiego) ułatwiały pokonanie bariery językowej. Podobnych do Ireny i Leona przykładów zachowań językowych w swoich wywiadach spotkałam jeszcze kilka. Żaden z badanych nie miał okazji do formalnej nauki języka hiszpańskiego, natomiast wszyscy podkreślali opanowanie języka hiszpańskiego w mowie i piśmie w stopniu co najmniej dobrym.

\section{Model 2. Polski językiem pierwszym, hiszpański językiem drugim przyswojonym w okresie dzieciństwa}

Ten rodzaj bilingwizmu polsko-hiszpańskiego jest typowy dla drugiej oraz kolejnych generacji Polonii argentyńskiej. W modelu tym język polski występuje jako pierwszy język przyswojony w domu rodzinnym, najczęściej w odmianie mówionej. W kilku badanych przypadkach pojawia się nauka języka polskiego w sposób sformalizowany albo w polskiej szkole, albo w szkole sobotniej, albo pod „czujnym okiem” jednego $\mathrm{z}$ rodziców lub dziadków.

Język hiszpański we wszystkich cytowanych przykładach przyswojono przed 12 rokiem życia, w trakcie nauki w argentyńskiej szkole. Respondenci opanowali bez większych problemów zarówno kod mówiony, jak i pisany, nie będąc przy tym rozpoznawanymi jako obcokrajowcy przez rodzimych użytkowników argentyńskiej odmiany hiszpańskiego.

Wśród badanych najwięcej osób prezentuje bilingwizm dwukulturowy. Pojawiają się także przypadki dwujęzyczności jednokulturowej, najczęściej na korzyść Polski.

Teofilia, Jorge oraz Zbyszek to reprezentanci drugiego modelu bilingwizmu polsko-hiszpańskiego w Argentynie:

Teofilia: przedstawicielka pierwszej generacji, urodzona w gminie Błażowa, w okolicach Rzeszowa, w 1928 r. Rok po jej narodzinach ojciec zdecydował się wyemigrować do Argentyny, aby trochę zarobić i jak najszybciej wrócić z powrotem do swojej rodziny. W tamtym czasie dużo mówiło się w Polsce o możliwościach pracy w Argentynie, która oferowała chętnym imigrantom ziemię. Rozdawano po wsiach ulotki i wiele rodzin 
decydowało się na emigrację. Ojciec był z zawodu stolarzem. Po przybyciu do Buenos Aires okazało się, że na miejscu też panował kryzys i nie było pracy dla wszystkich chętnych. Zatrudnił się więc przy zbiorach kukurydzy oraz ziemniaków. Cztery razy w roku wysyłał listy do matki, ze zdjęciami i pozdrowieniami dla córki. W 1936 r. matka podjęła trudną decyzję o emigracji. Wierzyła, że jej miejsce jest przy mężu, i pragnęła, żeby córka miała ojca. Teofilia miała dziewięć lat i dobrze pamięta podróż statkiem. Matka bardzo długo płakała, zaciskając w ręku torebkę wypełnioną ziemią ojczystą. Przeczuwała, że opuszcza kraj rodzinny na zawsze. Na statku wytłumaczyła córce, że jeśli umrze, to chce, aby pochowano ją z tą właśnie ziemią w butach. Trzy i pół tygodnia trwała podróż, którą obie, cierpiąc na chorobę morską, zniosły bardzo źle. W porcie w Buenos Aires czekał na nie ojciec Teofilii. Początkowo mieszkali we trójkę w jednym pokoju wynajmowanym od tureckiej rodziny. Raz w tygodniu szli do łaźni miejskiej, aby wziąć kąpiel. Buenos Aires zrobiło ogromne wrażenie na badanej: „bo takie duże i czyste, i jakie piękne sklepy; niczego tu nie brakowało".

Respondentka wspomina ze łzami w oczach historię swojej lalki - Marysi, którą własnoręcznie uszyła mama: „W przeddzień wielkiej podróży do Argentyny ja szukała mojej Marysi, ale nigdzie nie mogła jej znaleźć. Mama powiedziała, że jest już dawno spakowana do wielkiego kufra. Na miejscu łokazało się, że lalki nie było, bo mama musiała ją sprzedać (jak i wiele innych rzeczy), by móc łopłacić podróż. Z kolejną wypłatą ojciec kupił mi nową lalkę, ale nie była mi tak bliska jak Marysia. Ja czuła się strasznie samotna, bez babci, bez domu, bez ukochanych polskich pól i bez mojej Marysi”.

Relacje między rodzicami nie były łatwe. Matka Teofilii przez osiem lat była sama i nagle musiała na nowo podporządkować się mężowi, być od niego zależna. Nie znała języka i nie miała pracy. Była bardzo nieszczęśliwa. Próbowała sprzedawać własne wypieki, ale ludzie ją oszukiwali i czasami zamawiali po kilka ciast, po czym nie płacili. Nigdy nie nauczyła się hiszpańskiego w takim stopniu, by móc być niezależna. Córka jak mogła pomagała swojej matce, ale w pewnym momencie chciała się usamodzielnić i założyć własną rodzinę.

Teofilia poznała język hiszpański w szkole, do której trafiła pół roku po przybyciu do Argentyny. Przez pierwszy miesiąc miała prawo przysłuchiwania się i oglądania zajęć, bez czynnego udziału. Po kilku miesiącach znalazła się wśród najlepszych uczniów w klasie. Ukończyła szkołę średnią i poznała Polaka - byłego żołnierza, który przybył tuż po zakończeniu II wojny światowej. Wyszła za niego za mąż. Nie pracowała, zajmowała się domem. Nie mieli dzieci. Do dziś oboje udzielają się w „Ognisku Polskim” oraz w innych stowarzyszeniach polonijnych. Stworzyli polski dom na argentyńskiej ziemi. Matka Teofilii umarła młodo, w wieku 45 lat i została pochowana na cmentarzu w Buenos Aires. Zgodnie z jej wolą do butów nasypano polską ziemię z woreczka, który ze sobą przywiozła do Argentyny. Badana pytana o tożsamość, stwierdza, że czuje się Polką.

Respondentka spędziła w Argentynie ponad 75 lat, w związku z czym przyswoiła sobie bez większych problemów język hiszpański (kod mówiony oraz pisany), który jest dla niej funkcjonalnie drugim językiem. Jej mąż, który przybył do Argentyny jako dorosły mężczyzna, długo miał problemy z językiem kastylijskim. To Teofilia pomagała mu w redagowaniu podań, listów oraz innych dokumentów. 
Wywiad został przeprowadzony w całości w języku polskim, w odmianie potocznej z licznymi cechami gwarowymi (odmiana pierwszej osoby liczby mnogiej czasu przeszłego, labializacja nagłosowego „o” np. łosiem, łoczywiście).

Z historii opowiedzianej przez Teofilię wynika ważny problem wczesnego oraz późnego bilingwizmu (dwujęzyczności dzieci oraz dorosłych). Badani, którzy przybyli do Argentyny w dzieciństwie, zostali w krótkim czasie objęci obowiązkiem szkolnym i tym samym rozpoczęli formalną naukę języka, która zakończyła się sukcesem, to znaczy opanowaniem kodu mówionego oraz pisanego w stopniu równym rodzimym użytkownikom języka hiszpańskiego w Argentynie. Respondenci często wspominają swoich, nieżyjących już, rodziców i ich problemy z przyswajaniem nowego języka. W wielu przypadkach, jak świadczy o tym opisana historia matki Teofilii, język hiszpański pozostał dla emigrantów do końca życia językiem obcym.

Jorge: przedstawiciel pierwszej generacji urodzony w Wilnie w 1943 r. Miał pięć lat, kiedy rodzice zdecydowali się wyemigrować z Anglii, do której trafili pod koniec wojny wraz z innymi żołnierzami II Korpusu, do nowej ojczyzny - Argentyny. To była emigracja polityczna. Ojciec, były żołnierz, nie chciał wrócić do Polski komunistycznej. Trudne początki w Buenos Aires badany pamięta bardzo dobrze, bo nie znał języka hiszpańskiego i nie mógł porozumiewać się z rówieśnikami. Czuł się inny, gorszy. $\mathrm{W}$ domu mówiło się zawsze tylko po polsku, czego respondent się wstydził, bo jak wspomina, chciał być taki, jak jego koledzy z podwórka. Języka oficjalnego zaczął uczyć się w szkole podstawowej. Nie pamięta dokładnie, ile czasu zajęło mu przyswojenie hiszpańskiego, ale twierdzi, że nastąpiło to dosyć szybko. Przypomina sobie pierwszy dzień szkoły, kiedy mama nauczyła go przed wyjściem następującego zdania: „Soy polaco y no hablo castellano". Pamięta, że mówił to zdanie, a potem kolejne, nowe. Język polski pozostawał językiem rodzinnym, natomiast hiszpański był językiem szkoły, podwórka, rówieśników.

Badany skończył studia wyższe z fizyki, a następnie zrobił doktorat i dzisiaj pracuje na uniwersytecie w Buenos Aires jako wykładowca. Ma kontakty z Akademią Górniczo-Hutniczą w Krakowie, przez którą został zaproszony do poprowadzenia serii wykładów w roku 2005. Była to pierwsza okazja do odwiedzenia Polski, a także rodzinnego Wilna. Pytany o tożsamość, twierdzi, że jest pół-Polakiem i pół-Argentyńczykiem. Kocha polską kulturę. Zna całą literaturę do okresu dwudziestolecia międzywojennego. Jest stałym czytelnikiem Biblioteki Polskiej im. I. Domeyki w Buenos Aires, śpiewa także w chórze polonijnym. Ma żonę i troje dzieci, które niestety nie znają języka polskiego: „Nasze dzieci nie mówią po polsku i dzisiaj, kiedy są dorosłe, obwiniają mnie za to. Kiedy ja był mały, to nie chciał mieszać im w głowie. Ja myślał, że kiedy będą większe, to same zadecydują, czy chcą się uczyć, czy nie".

Wywiad został przeprowadzony w całości w języku polskim. Jest to odmiana kresowa polszczyzny, z charakterystycznym przedniojęzykowo-zębowym [ł] oraz z formami czasu przeszłego z zaimkiem osobowym jako wykładnikiem kategorii osoby (ja chodzit, ty chodzit itp.) Charakterystyczne jest także przedłużanie samogłosek w sylabach akcentowanych, cechujące polszczyznę kresową. 
Jak pokazują powyższe historie, badani są dwujęzyczni i czują swoją przynależność kulturową zarówno do Polski, jak i do Argentyny.

Następny respondent, pomimo całego życia spędzonego na argentyńskiej ziemi czuje się wyłącznie Polakiem:

Zbyszek: przedstawiciel drugiej generacji, urodzony w 1945 r. w Danii. Rodzice w czasie II wojny światowej znaleźli się w niemieckim obozie pracy, z którego udało się im uciec. Schronienie znaleźli w Danii. W 1948 r. zdecydowali się na emigrację do Argentyny. Respondent na statku obchodził swoje trzecie urodziny. Rodzina zamieszkała w Llavallol, w prowincji Buenos Aires. To tu właśnie rodzice znaleźli zatrudnienie w fabryce okien. Do piątego roku życia badany mówił wyłącznie po polsku. Jego starsza o dwa lata siostra pierwsza rozpoczęła argentyńską szkołę, więc czasami w domu mówiła po hiszpańsku. Z czasem rodzeństwo zaczęło między sobą rozmawiać właśnie w tym języku, jak twierdzi respondent: „było im prościej się dogadać”. Szkoła średnia oraz studia wyższe, których nie udało mu się ukończyć, to czas, w którym dominował język hiszpański, zarówno w życiu zawodowym, jak i osobistym. Badany ożenił się z Argentynką, na świat przyszło dwoje dzieci, które mają kontakt z językiem polskim wyłącznie w trakcie wizyt u polskich dziadków.

Zbyszek od młodości angażował się w pracę dla stowarzyszeń polonijnych. Mając własne dzieci, zrozumiał, że trzeba coś robić, aby młodzi także interesowali się przynależnością do stowarzyszeń i organizacji polonijnych. Wpadł na pomysł założenia polonijnego klubu sportowego dla młodzieży polonijnej i tym sposobem powstał „Polonia Futbol Club”, którego został prezesem. Jego syn dzięki przynależności do klubu i uczestnictwu w Igrzyskach Polonijnych w Toruniu w 2006 r. miał okazję poznać Polskę. Tak bardzo mu się spodobał kraj dziadków, że postanowił rozpocząć studia wyższe właśnie w Polsce. Najpierw przez rok uczył się języka polskiego w Krakowie, by potem rozpocząć studia na Politechnice Rzeszowskiej. Zbyszek jest bardzo dumny z wyboru syna i zazdrości mu świetnej znajomości języka polskiego. On sam rozumie i mówi bardzo dobrze, natomiast prawie wcale nie pisze. Stara się dużo czytać po polsku i to mu nieco pomaga w pisaniu, ale żałuje, że nie chodził w dzieciństwie do szkoły sobotniej. Obecnie badany jest już na emeryturze i pragnie całą swą uwagę skoncentrować wokół działalności polonijnego klubu sportowego, szukając nowych sponsorów, a także integrując młodzież argentyńską niepolskiego pochodzenia.

Pytany o tożsamość, odpowiada, że czuje się w 100\% Polakiem. Co ciekawe, dla Argentyńczyków jest Duńczykiem, ponieważ wszystkie oficjalne dokumenty wskazują na to właśnie obywatelstwo. Z Danią, poza miejscem urodzenia, nie ma nic wspólnego. Posiada argentyńską kartę stałego pobytu i stara się o polskie obywatelstwo.

Wywiad odbył się w całości w języku polskim, w odmianie literackiej, z licznymi elementami socjolektu polskiego-argentyńskiego.

Dla wszystkich badanych, reprezentujących drugi model dwujęzyczności polsko-hiszpańskiej w Argentynie, język polski jest językiem nacechowanym emocjonalnie, budzącym żywe uczucia związane ze wspomnieniami dzieciństwa, z najbliższą rodziną. Wiele $\mathrm{z}$ badanych domów należało do osób $\mathrm{z}$ wyższym wykształceniem, w związku z czym respondenci spotykali się najczęściej z polszczyzną literacką i w 
takiej odmianie ją zachowali do dziś. W większości przypadków respondenci przyznają, że ich dzieci nie znają języka polskiego. Fakt ten wskazuje na tendencję zatracania języka etnicznego przez trzecią generację wywodzącą się, w tych konkretnych przypadkach, z powojennej emigracji politycznej.

\section{Model 3. Język polski „słodkim wspomnieniem dzieciństwa”, hiszpański językiem kariery zawodowej. Zapominanie języka etnicznego i powroty do niego}

Ten rodzaj bilingwizmu hiszpańsko-polskiego jest popularny wśród współczesnej Polonii argentyńskiej i licznie reprezentowany zarówno przez przedstawicieli drugiej, jak i kolejnych generacji. Model ten zakłada przyswojenie języka polskiego w domu rodzinnym (wyłącznie polszczyzny mówionej), a potem wyparcie języka pierwszego przez język hiszpański, poznany w trakcie edukacji w argentyńskiej szkole. Język drugi staje się funkcjonalnie pierwszym, bo to w nim dokonuje się rozwój osobowościowy oraz intelektualny badanych. Po latach osoby te wracają do sformalizowanej nauki języka etnicznego, będącego „słodkim wspomnieniem dzieciństwa”. Przedstawiciele trzeciego modelu bilingwizmu prezentują dwujęzyczność dwukulturową lub zmierzającą w tym kierunku. Warto przywołać historie Laury, Marii oraz Alejandry.

Laura: przedstawicielka drugiej generacji, urodzona w Buenos Aires w roku 1940. Obecnie mieszka w prowincji Buenos Aires. Jest emerytowaną panią psycholog. Jej matka, pochodząca z małej miejscowości pod Kluczborkiem, przybyła do Argentyny „za chlebem” w roku 1930. W Polsce został jej narzeczony, który pięć lat później przyjechał do Argentyny. Na miejscu para wzięła ślub i jedyne, czego młodzi pragnęli, to zarobić pieniądze na zakup kawałka ziemi w Polsce. W 1938 r. oszczędności wysłali rodzinie - działka została kupiona, ale młodych zatrzymał w Argentynie wybuch II wojny światowej. Tymczasowa emigracja zarobkowa zamieniła się w emigrację na zawsze. Na świecie pojawiły się dwie córki - respondentka i rok później jej siostra. Ojciec zmarł dosyć szybko, więc to na mamie spoczywał obowiązek utrzymania rodziny. Była krawcową i sprzedawała do sklepów to, co sama uszyła. Piekła także na zamówienie torty i ciasta. Dom był polskim domem z tradycjami, kuchnią, wystrojem oraz językiem. Hiszpańskiego Laura nauczyła się dopiero w szkole i zrozumiała, że dzięki nauce może osiągnąć sukces oraz satysfakcję zawodową, a przede wszystkim odciążyć finansowo mamę. Mniej więcej $\mathrm{w}$ szkole średniej przestała używać języka polskiego i nawet w rozmowach z matką przechodziła szybko na hiszpański, w którym lepiej potrafiła się wyrazić. Po maturze zdała na wyższe studia psychologiczne, pracując jednocześnie jako sekretarka w międzynarodowej firmie. Oprócz polskiego i hiszpańskiego znała także język angielski. Po studiach Laura poznała swojego przyszłego męża - Argentyńczyka, wyszła za mąż, urodziła dwóch synów i rozpoczęła karierę zawodową.

Badana wspomina, że jej matka całe życie była nieszczęśliwa w Argentynie i chciała wrócić do Polski. Zmarła na zawał serca. Kiedy respondentka weszła do jej mieszkania, 
odkryła spakowaną walizkę i bilet lotniczy do Polski. Niestety, matka nie zdążyła zobaczyć swojej ukochanej ojczyzny.

Laura dopiero w momencie przejścia na emeryturę znalazła czas na „powrót do języka i kultury polskiej”. Zaczęła uczyć się języka etnicznego na kursie indywidualnym, a z czasem zapisała się na lektorat przy Universidad de Buenos Aires. Największym marzeniem Laury jest kurs języka polskiego w Polsce oraz poznanie rodziny. Jest bardzo ciekawa, co stało się z ziemią pod Kluczborkiem.

Z respondentką rozmowa toczyła się w dwóch językach, o sprawach prostszych, dotyczących codziennego życia mówiła z problemami gramatycznymi, ale po polsku. O rzeczach bardziej skomplikowanych, jak na przykład stosunek do języków oraz kultury obu krajów, w języku hiszpańskim.

Maria: przedstawicielka drugiej generacji, urodzona w Avellaneda (w prowincji Buenos Aires) w 1928 r. Rodzice pochodzili ze Lwowa i w 1926 r. wyemigrowali do Argentyny, gdyż jak mówi respondentka: „kraj rodzinny po odzyskaniu niepodległości w 1918 r. miał duże trudności gospodarcze i nie mógł zapewnić młodym ludziom dobrej przyszłości”. We Lwowie została starsza o dziesięć lat siostra badanej. Rodzice chcieli zarobić pieniądze, by móc wrócić i kupić w Polsce ziemię. Starszą córkę zostawili pod opieką ciotki - siostry ze strony matki. Po latach, kiedy okazało się, że sytuacja polityczna w Europie stawała się coraz bardziej napięta, rodzice pragnęli, by córka do nich dołączyła. Ona jednak była bardzo zakochana w swoim narzeczonym, z którym tuż przed wybuchem II wojny światowej wzięła ślub. Nie chciała opuszczać ojczystej ziemi.

Maria wychowywała się w domu przepełnionym patriotyzmem i przez całe dzieciństwo słyszała z ust rodziców, że wkrótce wrócą do Polski i że w końcu pozna swoją starszą siostrę oraz całą rodzinę. W domu mówiło się wyłącznie po polsku. Badana poznała hiszpański dopiero w szkole. Po zakończeniu II wojny światowej lwowska rodzina została przesiedlona do Gliwic. Na emigrację do Argentyny zdecydowała się w tym czasie siostra mamy, która zamieszkała wraz z rodzicami badanej pod jednym dachem. Maria ukończyła wyższe studia matematyczne i przez całe życie pracowała w liceum jako nauczycielka matematyki. Założyła własną rodzinę, urodziła syna. Po śmierci rodziców i ciotki przestała używać języka polskiego na co dzień. Do swojej siostry pisała listy i to był jedyny kontakt z językiem polskim. W 1994 r. rozpoczęła naukę języka polskiego najpierw indywidualnie, potem w grupie. W konsekwencji uczy się go nieprzerwanie od 18 lat, traktując to zajęcie jako hobby. W 1996 r. pojechała po raz pierwszy do Polski i spotkała się ze swoją siostrą, która była już bardzo chora. Obie miały jedyną i ostatnią okazję, aby porozmawiać. Siostra zmarła kilka dni później. W 2008 r. badana uczestniczyła w kursie języka polskiego w Krakowie, organizowanym przez „Wspólnotę Polską”. Po zakończonych zajęciach odwiedziła Lwów i odnalazła dom rodzinny, w którym zrobiła kilka pamiątkowych zdjęć. Badana wypowiedziała takie słowa: „Kiedy wspominam całą rodzinę, widzę, jak bardzo jesteśmy rozproszeni po różnych krajach świata: Ukraina, Polska, Argentyna, Włochy, Hiszpania. Myślę, że wszyscy jesteśmy świadomi swoich korzeni i że jest coś, co nas łączy: ta sama myśl, ta sama kultura, chociaż nie zawsze czujemy się Polakami”. Pytana o tożsamość, stwierdza, że jest Argentynką o polskich korzeniach. 
Wywiad odbył się w całości w poprawnym języku polskim, który od ostatnich 18 lat jest dla badanej językiem drugim. Maria twierdzi, że uczy się go na tyle intensywnie, że zaczyna myśleć oraz śnić po polsku, a to najlepsza oznaka jej dwujęzyczności.

Alejandra: przedstawicielka czwartej generacji, urodzona w Eldorado (w prowincji Misiones) w 1984 r. Z wykształcenia jest pedagogiem szkolnym. Pradziadkowie zarówno ze strony ojca, jak i matki przybyli z Polski do Argentyny w okolicach 1897 r.; należeli do grupy pierwszych Polaków zaludniających misjoneńską selwę. Ich celem była emigracja do Stanów Zjednoczonych, ale ograniczenia wizowe spowodowały, że znaleźli się w nieznanej Argentynie. Słowo „Polska” wywołuje u badanej takie skojarzenia, jak: korzenie, tradycja, rodzina. Alejandra bardzo lubi mówić po polsku. Języka nauczyli ją dziadkowie i to z nimi rozmawia do dzisiaj po polsku. Babcia od zawsze nazywa ją "Olą", czego w dzieciństwie nie lubiła, tak to wspomina: „,<ola> po hiszpańsku znaczy <cześć>, więc denerwowało mnie, kiedy babcia tak do mnie się zwracała. Z czasem przyzwyczaiłam się i dzisiaj lubię moje polskie imię". Rodzice Alejandry znają język polski dobrze, ale nie jest to język używany przez nich na co dzień.

Badana zachowuje polskie tradycje: imieniny, „Sto lat” - śpiewane na różne okazje, kolędy, opłatek, koszyczek, pisanki oraz dania kuchni polskiej. Bardzo często robi "pierogis", które smakują jej argentyńskiemu narzeczonemu. Marzy o prawdziwym polskim weselu.

W dzieciństwie lubiła czytać i przeglądać polskie książki, które były w domu. To było jej hobby, jej świat. Na pamięć znała mapę Polski przedrozbiorowej. W dorosłości przez trzy lata uczyła się języka polskiego w Związku Polaków w Posadas, a obecnie uczy się sama przez Internet. Ma przyjaciół w Polsce, poznanych głównie za pośrednictwem portalu społecznościowego „Facebook”, z którymi utrzymuje stały kontakt. Odnalazła także dalszych kuzynów, więc rozmawia z nimi za pomocą programu „Skype”. W społeczeństwie argentyńskim czuje się „,inna” ze względu na swoje polskie, trudne do wypowiedzenia nazwiska ${ }^{9}$ oraz słowiańską urodę. Jest dumna z polskich korzeni i z faktu, że zna tradycje oraz w stopniu podstawowym język swoich przodków. Marzeniem badanej jest możliwość odwiedzenia rodziny w Polsce i być może rozpoczęcie tam studiów.

Alejandra zna dobrze kod mówiony, natomiast prawie w ogóle nie pisze po polsku. Wywiad został przeprowadzony w dwóch językach. Socjolekt argentyńsko-polski badanej nosi liczne cechy gwarowe.

Warto przywołać fragment wypracowania w języku polskim, napisanego przez Laurę, w którym tłumaczy ona potrzebę powrotu do nauki języka rodziców, dziadków lub pradziadków. Myślę, że pod tymi słowami mogą podpisać się pozostali przedstawiciele trzeciego modelu bilingwizmu, bez względu na wiek, płeć, pochodzenie społeczne czy przynależność generacyjną:

Jako córka Polaków, zaczynałam mówić po polsku w domu. Potem upłynęło bardzo wiele lat, kiedy nie posługiwałam się językiem dziecięcych lat. Któregoś dnia, z jakiegoś

9 W krajach hiszpańskojęzycznych każda osoba posługuje się oficjalnie dwoma nazwiskami: pierwszym po ojcu, drugim po matce. 
zaułka serca, z racji intymnych i bardzo osobistych, zrodziła się we mnie chęć poznania głębiej języka, który słyszałam od kolebki. Usłyszeć owe słodkie słowa pełne dźwięczności, stare tradycyjne piosenki ludowe i religijne, poznać lepiej historię Polski czy nauczyć się, jak przygotowywać posiłki, które kochana mama stawiała z uśmiechem na stole. Nie wiadomo, dlaczego rozczulam się, śpiewając hymn polski, dlaczego zachwyca mnie młodzież wykonująca polskie tańce ludowe? A w czasie lekcji wydaje się, że można zwariować, ucząc się deklinacji polskich rzeczowników czy aspektów czasowników dokonanych i niedokonanych. Wydaje się, że nigdy nie będę pisać poprawnie - wydaje się, że dążę do jakiejś nieosiągalnej mety, coś w rodzaju kategorycznej zasady etycznej w pojęciu Kanta, coś, co może się stać w dalekiej przyszłości. Język z charakterystycznymi zdrobnieniami jak: babunia, mamusia, koteczek, Bozia itd., język pełen sentymentu, dziś wydaje mi się on trudny, ale jednocześnie piękny i umiłowany.

Jestem Argentynką, czuję się Polką i żywię głębokie uczucie do mowy polskiej, bo język ten to dla mnie Ojczyzna ${ }^{10}$.

\section{Model 4. Hiszpański językiem ojczystym, polski językiem obcym. W kierunku dwujęzyczności}

Biorąc pod uwagę fakt, że ostatnia liczna grupa emigrantów z Polski do Argentyny przybyła w połowie lat 50. wieku XX, coraz częściej spotyka się w tym kraju obywateli Argentyny polskiego pochodzenia, którzy uczą się języka polskiego jako obcego. Poszukiwanie własnej tożsamości, ciekawość, nostalgia, pragnienie podtrzymywania więzów rodzinnych tak z przodkami w Argentynie, jak i z rodziną w Polsce, motywacja ekonomiczna, studia w Polsce, chęć lepszego zrozumienia polskiej kultury (w szczególności literatury) - to najczęściej wymieniane przez badanych powody, dla których podjęli oni trud nauki języka polskiego.

Motywacja poznania języka polskiego w celu lepszego zrozumienia własnych korzeni oraz przekazanych przez przodków tradycji charakteryzuje reprezentantów czwartego modelu bilingwizmu hiszpańsko-polskiego, m.in. Héctora, Lilianę oraz Anę Julię. Oto ich historie:

Héctor: przedstawiciel trzeciej generacji, urodzony w kolonii Wanda (prowincja Misiones) w 1988 r. Rodzice ze strony ojca przybyli do tej kolonii w 1938 r., w obawie przed nadchodzącą wojną. Ojciec matki, były żołnierz II Korpusu, znalazł się w Argentynie w 1948 r., natomiast babka przybyła wraz z rodziną w 1936 r. „za chlebem”. Héctor $\mathrm{z}$ dziadkami rozmawiał trochę po polsku, ale ogólnie językiem domu rodzinnego był język hiszpański, chociaż wspomina, że rodzice czasami mówili między sobą po polsku. Od dzieciństwa tańczył w zespole polonijnym. Obecnie studiuje zarządzanie i marketing w Posadas. Języka polskiego uczył się przez dwa lata na kursie prowadzonym w Wandzie przez nauczycielkę z Polski (w latach 2006-2008). Dokonując samooceny, stwierdza, że rozumie i mówi po polsku dobrze, natomiast słabo czyta i pisze. Chce rozwijać

10 Zaprezentowany fragment tekstu, po drobnej korekcie, był pisemnym rozwinięciem odpowiedzi na pytanie zadane na prowadzonych przeze mnie zajęciach z języka polskiego (Buenos Aires, x 2010 r.): „Dlaczego uczycie się języka polskiego?”. 
znajomość języka, bo dzięki temu rozumie lepiej polskie tradycje, piosenki, ma większą łączność ze swoimi korzeniami. Uważa, że jest to jego obowiązek. Obecnie prowadzi blog poświęcony działalności Stowarzyszenia Polaków w Wandzie oraz pomaga w realizacji programu polonijnego nadawanego raz w tygodniu w lokalnym radiu.

Respondent nigdy nie był w Polsce i ma nadzieję, że uda się mu tam pojechać i być może rozpocząć studia.

Wywiad został przeprowadzony w połowie w języku polskim, w połowie w języku hiszpańskim, przy czym często respondent podejmował wysiłek rozpoczęcia zdania w języku polskim i w momencie, w którym brakowało mu odpowiedniego słowa, przechodził na język hiszpański i w tym języku kontynuował swoją wypowiedź.

Liliana: przedstawicielka czwartej generacji, urodzona w Posadas w 1969 r. Z wykształcenia jest adwokatem, jak również wykładowcą prawa na wyższej uczelni. Pradziadkowie ze strony ojca przybyli około 1905 r. z Galicji do argentyńskiego Misiones. Była to emigracja chłopska, zarobkowa. Dziadkowie ze strony matki znaleźli się w Misiones po wcześniejszym nieudanym pobycie w Brazylii. Pamięta, że rodzice ojca mówili w tym języku, ale był to ich sekretny język: kiedy chcieli sobie coś prywatnego powiedzieć, zawsze mówili po polsku. Żałuje, że w dzieciństwie nie rozmawiała z dziadkami w tym języku. Jej ojciec nie znał języka etnicznego, ale udzielał się w organizacjach polonijnych rozproszonych po misjoneńskiej prowincji.

W Polsce badana nigdy nie była, ale wyobraża ją sobie jako piękny kraj z kolorowymi domami, zamieszkanymi przez dobrych, pracowitych ludzi. Pytana o tożsamość, odpowiada, że czuje się Polką. Jej wygląd mówi sam za siebie: ma długie blond włosy, niebieskie oczy oraz jasną karnację: „Tu w Misiones jak jesteś rubio, to nazywają nas $<$ polacos>. Ja to bardzo lubię". Pradziadkowie Liliany utrzymywali korespondencję ze swoją rodziną i tradycja ta jest przekazywana z pokolenia na pokolenie. Dziś respondentka jest odpowiedzialna za kontakt - głównie mailowy - i jest to już czwarte pokolenie. W domu rodziców zachowała się cała korespondencja listowna, począwszy od $1905 \mathrm{r}$.

Badana bardzo lubi polski folklor. Ślub z Argentyńczykiem niepolskiego pochodzenia wzięła w polskiej parafii. Były polskie elementy na weselu: przywitanie gości chlebem i solą, tańce ludowe oraz polskie dania (m.in. bigos, barszcz, makowiec). Święta religijne mają stałe polskie elementy, takie jak: opłatek, pisanki, koszyczek. Często przyrządza pierogi, gołąbki czy barszcz. Jej dzieci uwielbiają polską kuchnię.

Języka polskiego uczy się od niedawna, uczestnicząc w zajęciach w Związku Polaków w Posadas. Niestety, nie mają nauczyciela z Polski. Cztery lata temu była polska nauczycielka w Wandzie, więc badana dojeżdżała raz w miesiącu na zajęcia. Odległość, którą musiała pokonać, to ponad $250 \mathrm{~km}$ w jedną stronę! Uważa, że warto było, bo dużo się nauczyła od pani Agnieszki. Język polski zna na poziomie średnio zaawansowanym. Jest dumna z faktu, że rozumie i że może swobodnie mówić. Dużo czyta, głównie w Internecie, oraz potrafi pisać. Należy do Związku Polaków w Posadas, w którym jako prawnik czuwa nad statutem. Uczestniczy w życiu religijnym i kulturalnym Polonii misjoneńskiej. W przyszłości pragnie zorganizować wymianę studencką pomiędzy polskimi wydziałami prawa a Universidad de Posadas, na którym wykłada. 
Wywiad został przeprowadzony w dwóch językach, przy czym wszystkie pytania zostały zadane w języku polskim. Badana sama decydowała o wyborze języka do danego pytania: na te trudniejsze udzielała odpowiedzi w języku hiszpańskim.

Ana Julia, ostatnia prezentowana respondentka, zaczęła uczyć się języka polskiego, bo poznała przez internet Polaka, w którym się zakochała. Trudno o lepszą motywację niż miłość, i mimo że ta nie przetrwała próby czasu, ciekawość językowa pozostała:

Ana Julia: przedstawicielka czwartej generacji, urodzona w La Plata (w prowincji Buenos Aires) w 1992 r. Studentka politologii. Dziadkowie ze strony matki wyemigrowali z Galicji w 1905 r. i osiedlili się w prowincji Chaco, natomiast dziadkowie ze strony ojca w tym samym czasie osiedlili się w Misiones. Zachowane w domu dokumenty pradziadków świadczą, że byli Austriakami, w związku z czym nikomu z rodziny nie udało się dostać polskiego obywatelstwa. W domu rodzinnym nikt nie mówił po polsku. Badana była nieco osłuchana z tym językiem, bo bywała na wakacjach u dziadków w Misiones. Uczestniczyła czasami w polskiej mszy lub w uroczystościach polonijnych. W wieku 17 lat poznała przez internet Polaka z Krakowa i jak twierdzi, zakochali się w sobie na odległość. Od tego czasu zaczęła się interesować wszystkim, co polskie. Zapisała się do Związku Polaków w Berisso. Dzięki wielkiemu zaangażowaniu respondentka otrzymała w 2009 r. stypendium Semper Polonia i możliwość wyjazdu na studia do Polski. W 2010 r. rozpoczęła intensywny kurs języka polskiego, przygotowujący do studiów w Polsce, który miał miejsce w Międzynarodowym Centrum Kształcenia na Politechnice Krakowskiej. W Krakowie spędziła rok i był to okres szybkiego dojrzewania do poważnych decyzji. Związek z polskim chłopcem nie przetrwał, a badana tak bardzo tęskniła za Argentyną, że po roku nauki postanowiła wrócić. Twierdzi, że poznani Polacy byli zamknięci i chłodni w relacjach. W trakcie swojego pobytu zrozumiała, że jest Argentynką. Tęskni za bigosem, pączkami i najlepszymi zapiekankami z krakowskiego Kazimierza. Z niektórymi znajomymi utrzymuje kontakt internetowy. Lubi mówić po polsku, twierdząc, że ,jest to bardzo bogaty język”. Przez rok bardzo intensywnej nauki doszła do poziomu dla średnio zaawansowanych. Pragnie kontynuować naukę, by w przyszłości móc wykorzystać znajomość języka polskiego w pracy zawodowej. Interesuje ją historia Polski. Chce specjalizować się w stosunkach polsko-argentyńskich.

Wywiad odbył się w całości w języku polskim. Informatorka wielokrotnie podkreślała swoje zadowolenie wynikające $\mathrm{z}$ faktu mówienia po polsku. Nagranie zostało przerwane po 25 minutach, ale $\mathrm{z}$ badaną rozmawiałyśmy przez około dwóch godzin.

Przywołane przy czwartym modelu bilingwizmu przykłady dotyczą świadomej nauki języka polskiego przez dorosłych. Dwujęzyczność hiszpańsko-polska jest w tych przypadkach na etapie kształtowania się i obecnie o jej naturalności możemy mówić jedynie w przypadku Any Julii. Zarówno Héctor, jak i Liliana prezentują sztuczny bilingwizm, będący w procesie kształtowania się.

Spoglądając przyszłościowo na Polonię argentyńską, mogę wyrazić opinię, że ten właśnie rodzaj bilingwizmu hiszpańsko-polskiego będzie coraz bardziej popularny. Przypadki stabilnej dwujęzyczności są coraz rzadsze, a jej miejsce zajmuje 
dwujęzyczność okazjonalna, do której pretenduje także model czwarty, w którym dominują język hiszpański oraz kultura argentyńska. Chęć odkrycia lub zrozumienia własnych korzeni i przekazywanych z pokolenia na pokolenie tradycji, wewnętrzny obowiązek wobec polskich przodków, motywacja ekonomiczna, studia lub praca w Polsce, motywacja „od polskiej kultury (w szczególności literatury) do języka" stają się bezpośrednim impulsem do nauki polszczyzny literackiej, w odmianie mówionej oraz pisanej. Proces przejścia z języka obcego w język drugi dokonuje się na różnych etapach życia badanych, a jego sukces jest uwarunkowany (analogicznie do modelu pierwszego) predyspozycjami osobowościowymi, talentem językowym oraz determinacją. Podsumuję fragmentem wiersza napisanego przez przedstawicielkę trzeciego pokolenia z Buenos Aires, czwarty rok uczącą się języka polskiego:

\section{[...] Miły język polski}

$\mathrm{Z}$ ust dziadków słyszany

Pierwszy raz w tych krajach.

Jestem twoim uczniem tutaj, języku kochany!

Z emigrantów polskich, w argentyńskim kraju.

\section{Podsumowanie}

Dwujęzyczność polsko-hiszpańska w Argentynie dla pierwszego i drugiego pokolenia polonijnego bliska jest zrównoważonej. Wśród najstarszych reprezentantów nie brak osób, które opanowały kody mówiony oraz pisany w obu językach w podobnym stopniu. U przedstawicieli kolejnych generacji przeważa bilingwizm dominujący, w którym to znajomość języka hiszpańskiego jest kompletna, natomiast kompetencja w języku polskim ogranicza się najczęściej do kodu mówionego.

W kraju, do którego ostatnia fala polskich emigrantów przybyła tuż po zakończeniu II wojny światowej, język polski coraz rzadziej pełni rolę języka ojczystego. Najczęściej spełnia funkcję języka drugiego lub obcego.

Relacje między modelem bilingwizmu polsko-hiszpańskiego, hiszpańsko-polskiego w Argentynie a pokoleniem polonijnym obrazuje Tabela 1.

Wart podkreślenia jest fakt, że współczesną Polonię argentyńską, jako grupę etniczną, charakteryzuje dwukulturowość oraz biwalencja, czyli podwójna przynależność kulturowa, przy czym nie zawsze relacje te pokrywają się z dwujęzycznością badanych. Mimo że teoretycznie nie wydaje się możliwe uznanie za własną kultury tworzonej w języku nieznanym sobie, w badaniach pojawiły się jednostki nieznające języka etnicznego lub posługujące się jedynie kodem mówionym, a podkreślające swą podwójną przynależność kulturową z Polską - ojczyzną ideologiczną i Argentyną - ojczyzną adopcyjną. Więzy emocjonalne, które reprezentanci Polonii argentyńskiej tworzą zarówno z krajem osiedlenia, jak i z 
krajem pochodzenia, świadczą o transnarodowym charakterze tej grupy. Efektem dwukulturowości i biwalencji staje się nowa tożsamość, powstała w wyniku konfrontacji kultury słowiańskiej z latynoską, którą można nazwać za Danutą Mostwin (1985) „trzecią wartością" Ponad połowa reprezentantów określa siebie mianem argentino-polaco, polacoo -argentino (Argentyno-Polak, Polako-Argentyńczyk). Neologizm ten oddaje charakter nowego typu tożsamości, ukształtowanego na styku kultur polskiej oraz argentyńskiej. Strukturę hybrydy kulturowej, powstałej w wyniku nakładania się na siebie dwóch różnych systemów wartości, można graficznie przedstawić w następujący sposób:

Schemat 1. Struktura hybrydy kulturowej zbiorowości polonijnej w Argentynie

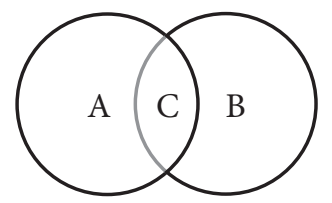

Źródło: opracowanie własne na podstawie Mostwin 1985.

Zbiór A reprezentuje system kultury polskiej, zbiór B system kultury argentyńskiej, natomiast zbiór C - hybrydę kulturową zbiorowości polonijnej, stanowiącą pogranicze dwóch różnych kultur. Z wypowiedzi respondentów wynika, że dla przedstawicieli pierwszej i drugiej

11 Mostwin badała polską powojenną emigrację polityczną w Stanach Zjednoczonych i Kanadzie i na podstawie badań psychologiczno-socjologicznych wyodrębniła tzw. Trzecią wartość kształtującą się na styku kultury polskiej, amerykańskiej i kanadyjskiej.

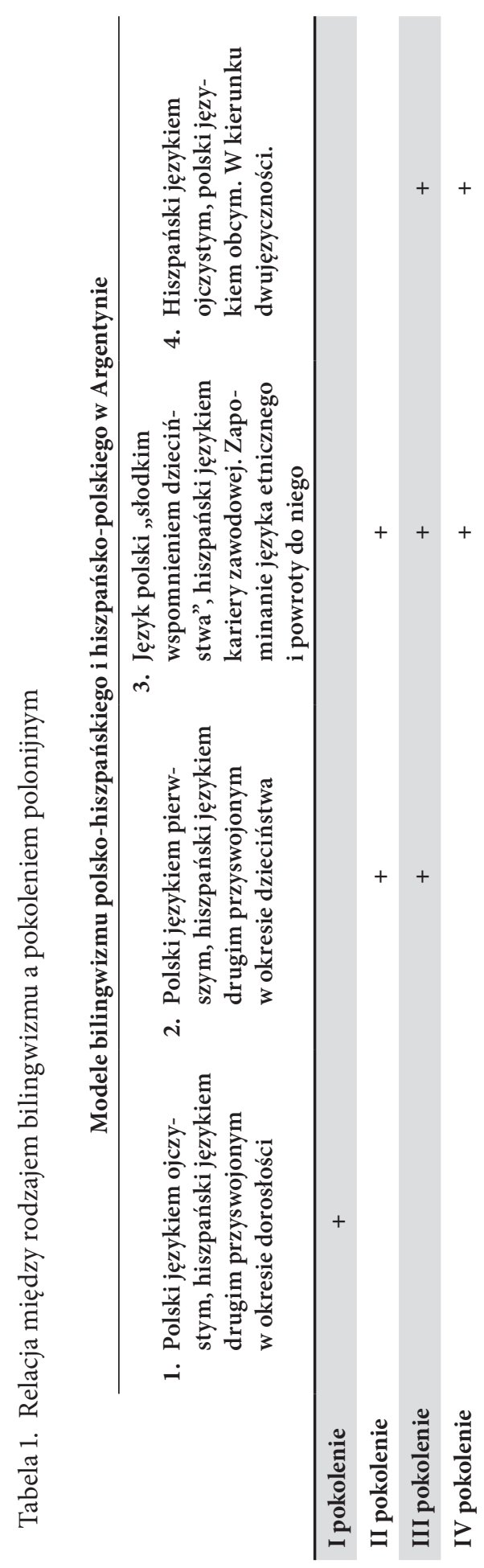


generacji podstawą tożsamości polsko-argentyńskiej jest polskość wzbogacona o elementy kultury argentyńskiej (język, nowe zwyczaje). Dla przedstawicieli trzeciego i czwartego pokolenia bycie Argentyno-Polakiem oznacza przewagę argentyńskości wzbogaconej polskimi elementami etnicznymi (język, folklor, polski system wartości). Identyfikacja dwukulturowa Polonii argentyńskiej jest stanem idealnym, gdyż pozwala jednostkom zachować psychiczną równowagę.

W przypadku Polonii argentyńskiej dwujęzyczność rozumiana jest przede wszystkim jako użycie dwóch języków (a także ich odmian środowiskowych, terytorialnych) w różnych sferach życia codziennego, przy czym to język hiszpański argentyński pełni funkcję J1. Język polski (w odmianie standardowej oraz interdialekcie) używany jest przede wszystkim podczas wizyt w kraju pochodzenia, a także w kontaktach z Polakami. Socjolekt polsko-argentyński jest używany najczęściej $\mathrm{w}$ dwujęzycznym środowisku polonijnym i stanowi rodzaj bilingwalnego modelu porozumiewania się. Pozwala on identyfikować się z określoną grupą społeczną, czyli z polską diasporą w Argentynie.

\section{Literatura}

Bryszewska M., Gmitruk J., Mazurek J. (red.), 2004, Polonia argentyńska w piśmiennictwie polskim. Antologia, Warszawa.

EPEıP: K. Dopierała et al. (red.), Encyklopedia Polskiej Emigracji i Polonii, Toruń 2003.

GDL\&SL: J. Dubois et al. (red.), Grand Dictionnaire de Linguistique \& Sciences du language, Paris 2008.

MAZUREK J., 2006, Kraj a emigracja. Ruch ludowy wobec wychodźstwa chłopskiego do krajów Ameryki Łacińskiej (do 1939 roku), Warszawa.

Miodunka W., 2003, Bilingwizm polsko-portugalski w Brazylii. W stronę lingwistyki humanistycznej, Kraków.

Mostwin D., 1985, Trzecia wartość. Formowanie się nowej tożsamości polskiego emigranta w Ameryce, Lublin.

Pyzik S., 1966, Los Polacos en la República Argentina y América del Sur desde el año 1812, Buenos Aires.

Stemplowski R. (red.), 2011, Polacy, Rusini i Ukraińcy, Argentyńczycy. Osadnictwo w Misiones 1892-2009, Warszawa.

Uzarowicz T.M., 1988, Inmigración polaca en la Argentina (1946-1950), „V jornada de historia de la ciudad de Buenos Aires", Buenos Aires.

WróBel H., 1999, Historia duszpasterstwa polskiego w Argentynie w latach 1897-1997, Warszawa. WRÓBLEWSKA-PAWLAK K., 2004, Język - tożsamość - emigracja. O strategiach adaptacyjnych Polaków zamieszkałych we Francji w latach osiemdziesiątych XX wieku, Warszawa. 


\section{Models of becoming and being bilingual in Polish diaspora in Argentina Summary}

The present paper is the effect of field work on Polish-Spanish bilingualism in Polish diaspora in Argentina, conducted in years 2009-2011 in the provinces of Buenos Aires, Santa Fe, Córdoba, and Misiones. It portrays four models of bilingualism which define the modern Polish diaspora in Argentina, each illustrated with linguistic biographies of selected respondents. The change of the research perspective from a purely linguistic to an interdisciplinary one, has allowed a wide analysis of the phenomenon of bilingualism to be performed, together with its impact on the creation and metamorphosis of identity and cultural valency of four generations of Poles living in Argentina. 